ҚАЗАҚСТАН РЕСПУБЛИКАСЫ

ҰЛТТЫҚ ҒЫЛЫМ АКАДЕМИЯСЫНЫН

АБАЙ АТЫНДАҒЫ ҚАЗАҚ ҰЛТТЫҚ

ПЕДАГОГИКАЛЫҚ УНИВЕРСИТЕТІНІҢ

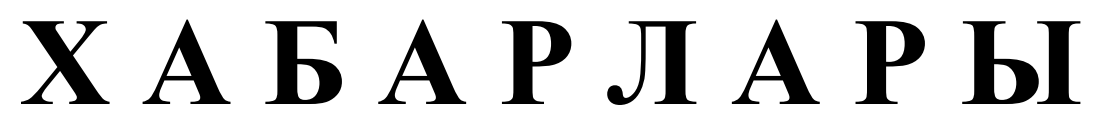

\section{ИЗВЕСТИЯ}

НАЦИОНАЛЬНОЙ АКАДЕМИИ НАУК РЕСПУБЛИКИ КАЗАХСТАН

КАЗАХСКИЙ НАЦИОНАЛЬНЫЙ

ПЕДАГОГИЧЕСКИЙ УНИВЕРСИТЕТ ИМ. АБАЯ

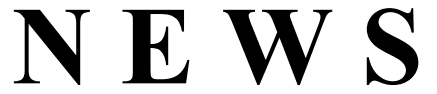

OF THE NATIONAL ACADEMY OF SCIENCES OF THE REPUBLIC OF KAZAKHSTAN

ABAY KAZAKH NATIONAL PEDAGOGICAL UNIVERSITY

ҚОҒАМДЫҚ ЖӘНЕ ГУМАНИТАРЛЫҚ ҒЫЛЫМДАР СЕРИЯСЫ

СЕРИЯ ОБЩЕСТВЕННЫХ И ГУМАНИТАРНЫХ НАУК

$\checkmark$

SERIES OF SOCIAL AND HUMAN SCIENCES

$$
5 \text { (321) }
$$

КЫРКУЙЕК - КАЗАН 2018 ж.

СЕНТЯБРЬ - ОКТЯБРЬ 2018 Г.

SEPTEMBER - OCTOBER 2018

1962 ЖЫЛДЫҢ ҚАНТАР АЙЫНАН ШЫҒА БАСТАҒАН

ИЗДАЕТСЯ С ЯНВАРЯ 1962 ГОДА

PUBLISHED SINCE JANUARY 1962

ЖЫЛЫНА 6 РЕТ ШЫҒАДЫ

ВЫХОДИТ 6 РАЗ В ГОД

PUBLISHED 6 TIMES A YEAR 
Ба с ре дактор

ҚР ҰҒА кұрметті мүшесі

Балықбаев Т.O.

Р е д а ц и я а лқ а сы:

экон. ғ. докторы, проф., ҚР ҰҒА академигі Баймұратов У.Б.; тарих ғ. докторы, проф., ҚР ҰҒА академигі Байпақов К.М.; филос. ғ.докторы, проф., ҚР ҰҒА академигі Есім Г.Е.; фил. ғ. докторы,, проф., ҚР ҰҒА академигі Қирабаев С.С.; эк. ғ. докторы, проф., ҚР ҰҒА академигі Кошанов А.К.; эк.ғ. докторы, проф., ҚР ҰҒА академигі Нәрібаев К.Н. (бас редактордың орынбасары); филос. ғ.докторы, проф., ҚР ҰҒА академигі Нысанбаев А.Н.; заң ғ. докторы, проф., ҚР ҰҒА академигі Сәбікенов С.Н.; заң ғ. докторы, проф., ҚР ҰҒА академигі Сүлейменов М.К.; эк. ғ. докторы, проф., ҚР ҰҒА академигі Сатыбалдин С.С.; тарих ғ. докторы, проф., ҚР ҰҒА академик Әбжанов Х.М.; тарих ғ. докторы, проф., ҚР ҰҒА корр. мүшесі Әбусеитова М.Х.; тарих ғ. докторы, проф., ҚР ҰҒА академик Байтанаев Б.А.; филол. ғ. докторы, проф., ҚР ҰҒА корр. мүшесі Жақып Б.А.; фил. ғ. докторы, проф., академик НАН РК Қалижанов У.К.; филол. ғ. докторы, проф., ҚР ҰҒА академик Қамзабекұлы Д.; тарих ғ. докторы, проф., ҚР ҰҒА академик Қожамжарова Д.П.; тарих ғ. докторы, проф., ҚР ҰҒА академик Койгелдиев М.К.; фил. ғ. докторы, проф., ҚР ҰҒА корр. мүшесі Кұрманбайұлы Ш.; тарих ғ. докторы, проф., ҚР ҰҒА корр. мүшесі Таймағанбетов Ж.К.; социол. ғ. докторы, проф., ҚР ҰҒА корр. мүшесі Шәукенова 3.К.; фил. ғ. докторы, проф., КР ҰҒА корр. мүшесі Дербісәлі А.; саяси. ғ. докторы, проф., Бижанов А.К., тарих ғ. докторы, проф., Кабульдинов 3.Е.; фил. ғ. докторы, проф., ҚР ҰҒА корр мүшесі Қажыбек Е.3.

\section{Р едакция ке н е с i:}

Молдова Республикасының ҰҒА академигі Белостечник Г. (Молдова); Әзірбайжан ҰҒА академигі Велиханлы Н. (Азербайджан); Тәжікстан ҰҒА академигі Назаров Т.Н. (Тәжікстан); Молдова Республикасының ҰҒА академигі Рошка А. (Молдова); Молдова Республикасының ҰҒА академигі Руснак Г. (Молдова); Әзірбайжан ҰҒА корр. мүшесі Мурадов Ш. (Әзірбайжан); Әзірбайжан ҰҒА корр. мүшесі Сафарова 3. (Әзірбайжан); э. ғ. д., проф. Василенко В.Н. (Украина); заң ғ. докт., проф. Устименко В.А. (Украина)

«Қазақстан Республикасы Ұлттық ғылым академиясының Хабарлары. Қоғамдық және гуманитарлық ғылымдар сериясы». ISSN 2224-5294

Меншіктенуші: «Қазақстан Республикасының Ұлттық ғылым академиясы» РҚБ (Алматы қ.)

Қазақстан республикасының Мәдениет пен ақпарат министрлігінің Ақпарат және мұрағат комитетінде 30.04.2010 ж. берілген № 10894-Ж мерзімдік басылым тіркеуіне қойылу туралы куәлік

Мерзімділігі: жылына 6 рет.

Тиражы: 500 дана.

Редакцияның мекенжайы: 050010, Алматы қ., Шевченко көш., 28, 219 бөл., 220, тел.: 272-13-19, 272-13-18, http://nauka-nanrk.kz. social-human.kz

(C) Қазақстан Республикасының Ұлттық ғылым академиясы, 2018

Типографияның мекенжайы: «Аруна» ЖК, Алматы қ., Муратбаева көш., 75. 
Главный редакто $p$

Почетный член НАН РК

T.O. Балыкбаев

Р е дак ци онн а я коллег и я:

докт. экон. Н., проф., академик НАН РК У.Б. Баймуратов; докт. ист. н., проф., академик НАН РК К.М. Байпаков; докт. филос. Н., проф., академик НАН РК Г.Е. Есим; докт. фил. Н., проф., академик НАН РК С.С. Кирабаев; докт. экон. Н., проф., академик НАН РК А.К. Кошанов; докт. экон. Н., проф., академик НАН РК К.Н. Нарибаев (заместитель главного редактора); докт. филос. н., проф., академик НАН РК А.Н. Нысанбаев; докт. юр. Н., проф., академик НАН РК С.Н. Сабикенов; докт. юр. н., проф., академик НАН РК М.К. Сулейменов; докт. экон. Н., проф., академик НАН РК С.С. Сатубалдин; докт. ист. н., проф., академик НАН РК Х.М. Абжанов; докт. ист. н., проф., чл.-корр. НАН РК М.Х. Абусеитова; докт. ист. н., проф., академик НАН РК Б.А. Байтанаев; докт. фил. н., проф., чл.-корр. НАН РК Б.А. Жакып; докт. фиолол. н., проф., академик НАН РК У.К. Калижанов; докт. фил. н., проф., академик НАН РК Д. Камзабекулы; докт. ист. н., проф., академик НАН РК Д.П. Кожамжарова; докт. ист. н., проф., академик НАН РК М.К. Койгельдиев; докт. филол. н., проф., чл.-корр. НАН РК Ш. Курманбайулы; докт. ист. н., проф., чл.корр. НАН РК Ж.К. Таймаганбетов; докт. социол. н., проф., чл.-корр. НАН РК З.К. Шаукенова; д. филол. н., проф., чл.-корр. НАН РК А. Дербисали; доктор политических наук, проф., Бижанов А.К.; доктор ист. наук, проф., Кабульдинов 3.Е.; доктор филол. н., проф., член-корр. НАН РК Қажыбек Е.3.

Р е дак ци онны й с ов е т

академик НАН Республики Молдова Г. Белостечник (Молдова); академик НАН Азербайджанской Республики Н. Велиханлы (Азербайджан); академик НАН Республики Таджикистан Т.Н. Назаров (Таджикистан); академик НАН Республики Молдова А. Рошка (Молдова); академик НАН Республики Молдова Г. Руснак (Молдова); чл.-корр. НАН Азербайджанской Республики Ш. Мурадов (Азербайджан), член-корр. НАН Азербайджанской Республики 3.Сафарова (Азербайджан); д. э. н., проф. В.Н. Василенко (Украина); д.ю.н., проф. В.А. Устименко (Украина)

Известия Национальной академии наук Республики Казахстан. Серия общественных и гуманитарных наук. ISSN 2224-5294

Собственник: РОО «Национальная академия наук Республики Казахстан» (г. Алматы)

Свидетельство о постановке на учет периодического печатного издания в Комитете информации и архивов

Министерства культуры и информации Республики Казахстан № 10894-Ж, выданное 30.04.2010 г.

Периодичность 6 раз в год

Тираж: 500 экземпляров

Адрес редакции: 050010, г. Алматы, ул. Шевченко, 28, ком. 219, 220, тел. 272-13-19, 272-13-18, www:nauka-nanrk.kz / social-human.kz

(C) Национальная академия наук Республики Казахстан, 2018 г.

Адрес типографии: ИП «Аруна», г. Алматы, ул. Муратбаева, 75

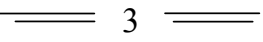


Chief Editor

\section{Honorary member of NAS RK \\ Balykbayev T.O}

Editorial board:

Doctor of economics, prof, academician of NAS RK Baimuratov U.B.; doctor of history, prof, academician of NAS RK Baipakov K.M.; doctor of philosophy, prof, academician of NAS RK Esim G.E.; doctor of philology, prof, academician of NAS RK Kirabayev S.S.; doctor of economics, prof, academician of NAS RK Koshanov A.K.; doctor of economics, prof, academician of NAS RK Naribayev K.N. (deputy editor-in-chief); doctor of philosophy, prof, academician of NAS RK Nyssanbayev A.N.; doctor of law, prof, academician of NAS RK Sabikenov S.N.; doctor of law, prof, academician of NAS RK Suleymenov M.K.; doctor of economy, prof, academician of NAS RK Satybaldin S.S.; doctor of history, prof, academician of NAS RK Abzhanov H.M; doctor of history, prof, corresponding member of NAS RK Abuseitova M.H.; doctor of history, prof, academician of NAS RK Baitanaev B.A.; doctor of philology, prof, corresponding member of NAS RK Zhakyp B.A.; doctor of philology, prof, academician of NAS RK Kalizhanov U.K.; doctor of philology, prof, academician of NAS RK Hamzabekuly D.; doctor of history, prof, academician of NAS RK Kozhamzharova D.P.; doctor of history, prof, academician of NAS RK Koigeldiev M.K.; doctor of philology, prof, corresponding member of NAS RK Kurmanbaiuly Sh.; doctor of history, prof, academician of NAS RK Taimaganbetov J.K.; doctor of sociology, prof, corresponding member of NAS RK Shaukenova Z.K.; doctor of philology, prof, corresponding member of NAS RK Derbisali A.; doctor of political science, prof Bizhanov A.K; doctor of History, prof Kabuldinov Z.E.; doctor of philology, prof, corresponding member of NAS RK Kazhybek E.Z.

\section{Editorial staff:}

Academician NAS Republic of Moldova Belostechnik.G (Moldova); Academician NAS Republic of Azerbaijan Velikhanli N. (Azerbaijan); Academician NAS Republic of Tajikistan Nazarov T.N. (Tajikistan); Academician NAS Republic of Moldova Roshka A. (Moldova) Academician NAS Republic of Moldova Rusnak G. (Moldova); Corresponding member of the NAS Republic of Azerbaijan Muradov Sh. (Azerbaijan); Corresponding member of the NAS Republic of Azerbaijan Safarova Z. (Azerbaijan); Associate professor of Economics Vasilenko V.N. (Ukraine), Associate professor of Law Ustimenko V.A. (Ukraine)

News of the National Academy of Sciences of the Republic of Kazakhstan. Series of Social and Humanities. ISSN 2224-5294

Owner: RPA "National Academy of Sciences of the Republic of Kazakhstan" (Almaty)

The certificate of registration of a periodic printed publication in the Committee of information and archives of the Ministry of culture and information of the Republic of Kazakhstan N 10894-Ж, issued 30.04.2010

Periodicity: 6 times a year

Circulation: 500 copies

Editorial address: 28, Shevchenko str., of. 219, 220, Almaty, 050010, tel. 272-13-19, 272-13-18, www:nauka-nanrk.kz / social-human.kz

(C) National Academy of Sciences of the Republic of Kazakhstan, 2018

Address of printing house: ST "Aruna", 75, Muratbayev str, Almaty 
N E W S

OF THE NATIONAL ACADEMY OF SCIENCES OF THE REPUBLIC OF KAZAKHSTAN

SERIES OF SOCIAL AND HUMAN SCIENCES

ISSN 2224-5294

https://doi.org/10.32014/2018. 2224-5294.4

Volume 5, Number 321 (2018), 26 - 32

UDK 929, IRSTI 03.20

D.A.Kenzhebayev ${ }^{1}$

${ }^{1}$ Military and engineering institute of radio electronics and communication, Almaty, Kazakhstan E-mail: daulet.0117@rambler.ru

\title{
THE SARYSHAGAN GROUND - THE SHORT HISTORICAL ANALYSIS
}

\begin{abstract}
Centuries-old history of Kazakhstan is the richest well of historical events which often characterized by global scales of their consequences. Geographically connecting the European states with the Asian countries, Kazakhstan in the historical development sometimes had the most direct influence on relationship of the world states. Similar interrelations come to light in the context of historical researches of geopolitical confrontations caused by the development of science, the equipment and technologies in the sphere of providing military safety and development of military art. In this regard in the modern conditions the military space direction of scientific search in general and historical researches in particular is actualized. The territory of the Republic of Kazakhstan historically reasonably became the homeland and the center of the embodiment of a practical celebration of a scientific thought in the sphere of development of space-rocket technologies that in turn staticizes carrying out additional researches the purpose of which must to be a definition of historic facts and the defining events in a complex of the manifestation caused the existing order of things and a conjuncture of interstate relationship. In the context of told in this article historical experience of implementation in the territory of Kazakhstan, one of components of military space activity which is development of antimissile component is considered. Within the provided analysis, the historical prerequisites and conditions of formation of this direction of the state activity in a section of a historiography of her origin and further development in modern conditions are revealed. Actions of public authorities at the historical moment of disintegration of the Soviet state and formation of independent Kazakhstan are shown, results of interstate arrangements are revealed; the prospects of their further execution are defined. In general, leaning on a number of new sources, the impartial view of a historiography of historical development of system of missile defense in the context of disclosure of content of the related activity which is carried out in the territory of Kazakhstan is presented.
\end{abstract}

Key words: Saryshagan, Balkhash hub, missile warning system.

\section{Introduction}

The historical analysis of implementation of space-rocket activity in the territory of Kazakhstan, being the highly specialized direction of domestic historical science, has undoubted relevance that is defined as current trends of the theory and practice of military science, so requirement of society and state to expansion of the available knowledge of national history for defining the optimum directions of further development [1]. In the context of told it is noted that modernization of arms since ancient times was carried out by the principle of mutual confrontation of attack and defense instruments: to a sword the shield resisted, to spears and arrows - armor and a chain mail, to a shell - armor, to a rocket - the systems of missile defense. In this regard, the short historical analysis of the state activities for development of working out in the sphere of development of the system of warning of missile attack and control of space is of adequately by the relevant and being of interest research.

\section{Methods}

During the research, the combination of general scientific and historical methods of scientific research, which are the analysis of a problem and a chronological method of its statement were used. Thus, it was succeeded to isolate the defining events of national history which have caused change of dynamics and the directions of a course of the considered historical process. 


\section{Results}

Intensive development of nuclear missile arms has caused need of development and the fastest commissioning of reliable remedies of counteractions. For this purpose, from the middle of the 1950th years under the leadership of G.V. Kisunko specially created design bureau (SKB-30) has started research and development projects on formation of theoretical bases and development of practical products in the field of missile defense. The first steps which are carried out in this direction have caused the necessity of carrying out full-scale natural experiments. For implementation of these actions in the territory of Kazakhstan near Lake Balkhash (on its northwest side) near the Saryshagan station in July, 1956 the construction of the State research and proving ground No. 10 of the Ministry of Defence (No. 10 GNIIP) has begun [2 Page 51-52].

On the ground the development and tests of an experimental complex of missile defense was conducted (system "A"), during which ways of creation the effective remedies of defeat of intercontinental ballistic missiles of the possible opponent were fulfilled. As a result of the executed actions the first-ever successful defeat of a ballistic missile by an antimissile has been carried out on March 4, 1961. The medium-range missile R-12 launched from the 4th State Central Ground (SCG) "Kapustin Yar" after its localization on a distance of $1500 \mathrm{~km}$ at the height of $25 \mathrm{~km}$ has been destroyed in the automatic mode by the V-1000 antimissile, which were started from the State research and proving ground No. 10 of Saryshagan (there were in total 11 tests on hitting the R-5M and R-12 ballistic missiles). Further for determination of operability of radio-electronic means in the conditions of impact of high-rise nuclear explosions the Soviet Union government initiated carrying out of a series of the special test operations designated by a letter "K": the operations "K1", "K2" - in October, 1961, the operation "K3" - "K5" - in October, 1962. During tests about two rockets were let into the region of GNIIP No. 10 "Saryshagan" from GTsP "Kapustin Yar", first of which has been supplied with a nuclear charge. At approach to system "A" the nuclear charge blasted and then the possibility of hitting targets by an antimissile in the conditions of the nuclear explosion factors was examined [3]. In the subsequent the uniqueness of this object in the context of a possibility of carrying out tests of perspective weapon for long time has provided its necessity in military circles even in the conditions of the post-Soviet geopolitics [4].

On August 5, 1963 in Moscow the Agreement between the USSR and the USA "About prohibition of nuclear explosions in the atmosphere, in space and under water" has been signed [5], however by the time in the Soviet Union polygon tests of the relevant products, evidently confirming the potential possibility of the intercontinental ballistic missiles destruction before their approach to the object including conditions of influence of the nuclear explosions factors, have been already executed. Thus, the Soviet military science was enriched with the valuable skilled data which results have formed the basis of creation of the whole direction of the space-rocket industry in the sphere of development of systems and means of missile and antispace defense, having allowed to create in a consequence the effective system of cover of the important administrative centers of the country from potentially possible blows of the opponent.

Creation of above-the-horizon radar stations became a progressive step in development of systems of missile defense as a result of which on the State research and proving ground No. 10 (Saryshagan) since 1973 the radar knot on the basis of Dniester 5H15 and 5H86 Dnieper radar stations (entering the missile warning system and control of space) has been equipped and put into operation which forces and means successfully solved problems of detection of artificial Earth satellites [6 Page 211-214].

The Almaty technological enterprise of Granit concern of the Ministry of the radio industry of the USSR created in 1976 became lead agency of the Soviet Union in the field of implementation of installation and test works of the radio-electronic equipment of the complexes of the missile warning system tested on the Saryshagan ground. This organization has made the powerful contribution to development and modernization of many perspective samples of arms of missile and air defense; and also participated in creation of control systems of the Buran spaceship [7].

Thus, the State research and proving ground No. 10 of the Ministry of Defence (Saryshagan) located in the territory of the Kazakh SSR has been involved in the structure of actively operating military space branch of the Soviet state. Capability of the ground were used as for development and tests (in interaction with GTsP "Kapustin Yar") means of missile defense in various conditions, so for the organization of continuous monitoring of space regarding detection of artificial Earth satellites and a warning of missile attack. The general specifics of the carried-out tasks of objects assumed their further scientific and 
technical development in the context of formation of united system of aerospace defense. However, the socio-political realities which have followed in the USSR have caused other way of succession of events.

In 1985-1988 under the leadership of M.S. Gorbachev in the Soviet Union a number of the reforms which have affected the system of public administration, foreign and domestic policy of the country, her economy, armed forces and some questions of ideology has been initiated [8]. At the heart of the accepted policy of "New thinking" acceleration of social and economic development of the country, reorganization of all parties of public and foreign policy strategy of the CPSU, restraint of a race of arms, democratization of the international relations and peaceful co-existence with the states with various social order was proclaimed. However as has shown time, in fact, the result of the chosen way of public administration became the chain of the historical events differing by its extreme character and irreversibility of consequences. The internal political situation caused by crash of economic system, commodity and grocery crisis, a hyperinflation, political confrontations in the highest echelons of the government and also escalation of a series of the international conflicts has sharply become aggravated in the country (December events in Kazakhstan - 1986; Novouzensky and Tbilisi events, the Karabakh and Georgian-South Ossetia conflicts, the conflict in the Fergana Valley - 1989; the conflicts in Baku, Dushanbe, Yerevan - 1989; Baltic region - 1989 and some other).

The social tension increasing in the state has caused rapid development of centrifugal forces. In the 1988-90th years in the USSR occurs, so-called, the "parade of sovereignties" caused by the declaration of a priority of republican laws over all-union [9]. On December 8, 1991 heads of the Russian Federation, Republic of Belarus and Ukraine have signed the Agreement on creation of the Commonwealth of Independent States [10 Page 50-51]. In a prompt stream of the occurring events the contemporary history of Kazakhstan also developed: On October 25, 1990 the Supreme Council of the Kazakh SSR has adopted the Declaration on the state sovereignty [11]; On December 16, 1991 the Republic of Kazakhstan has declared the state independence [12], and on December 21 the same year signing of the Almaty Declaration entered the Commonwealth of Independent States [13].

In the conditions of socio-political processes tormenting the agony Soviet state full activity of various institutes consisting its statehood became almost impossible. The situation was aggravated with destruction of interrepublican communications of economic, production and scientific character.

Progressing "disease" of society has affected also moral atmosphere in his Armed forces. The people bearing military service have faced the necessity of solution of a difficult dilemma: on the one hand they have been obliged to remain faithful to the military duty and, carrying out the official duties, to ensure military safety of the state; with another - they were resisted by the uncertainty of the near future caused by the outlined disintegration of once united country. Besides, emerging sovereign states quickly sought to create the national armies. Thus, further successful functioning of military space branch has appeared under the threat of the elimination.

On August 24, 1991 M.S. Gorbachev has resigned of the Secretary general of the Central Committee of the CPSU and has expressed the idea about expediency of self-dissolution of the Central Committee of the CPSU [14 Page 319]. On August 30, 1991 he has abolished military-political bodies in army and on the fleet [15]. These events has negatively affected already low level of a moral and psychological condition of troops and not in the best way stabilized the situation in army. The military discipline of staff has weakened, among the military personnel of conscription service the discontent facts, warmed up on the national soil began to be shown, cases of unauthorized leaving of a part and mass desertion have become frequent.

In the conditions of lack of the personnel, economic, technical and technological potential, necessary for independent operation of proving grounds, by the country leaders into the forefront paramount tasks were taken out - first of all, it was necessary to safe military facilities from destruction and plunders and to provide their working capacity for future generations.

Thus, thanks to forward-looking policy of the President of Kazakhstan N.A. Nazarbayev the territorial principle of accessory of earlier allied objects of military space infrastructure has been defined [16]. On May 7, 1992 the decree of the President of the Republic of Kazakhstan has created Armed forces of independent Kazakhstan [17]. Construction of the military organization of the state has begun.

In June-July, 1992 the Cabinet of ministers of RK has organized preparation of documents for a meeting of Council of heads of states of the CIS. Development of the draft agreement on means of missile 
warning systems and control of space [18] became one of the raised questions. As a result of carried out on July 6, 1992 in Moscow official meeting - "The agreement on means of missile warning systems and control of space" has been signed, according to which the property right to means of missile warning system and the space control system was assigned to the states in the territory of which they accommodate, the possibility of transfer of the rights of use by the sides on the basis of separate agreements and some other questions in the field of interstate relationship is stipulated, the structure of systems, an order of their fighting functioning, management and providing the State Parties with output information was defined [19].

In July of the 1993rd, considering the facts of illegal export of property of military units and industrial enterprises of defense industry out of RK - by the order of the Prime minister of RK has formed the commission on inventory and acceptance in maintaining state bodies of RK of property of military units, industrial enterprises and organizations of Baikonur Cosmodrome and the objects of space infrastructure located in the territory of RK, the Saryshagan, Semipalatinsk and Emba grounds [20]. The commission was obliged to accept objects on proving grounds, property of the military units, enterprises and organizations located or which are carrying out the activity in the territory of RK on balance of state bodies for what she has been given the right to attract to work of specialists of the regional, city administrations, ministries and departments of RK. Thus, the leaders of the state carried out actions for the organization of accounting of arms and military equipment, property and other material values of the military units deployed in the territory of Kazakhstan, to prevention of his plunder and adoption of the reasonable decision on expediency of further use.

On March 28, 1994 between the Republic of Kazakhstan and the Russian Federation the Agreement on military cooperation, among other, the defined status and an order of use of the Russian Strategic nuclear forces deployed in the territory of Kazakhstan and in the subsequent formed the basis for adoption of many important interstate agreements has been signed [21], [22].

Within performance of the Agreement on means of missile warning systems and control of space (of July 6, 1992) - on December 14, 1994 the Governments of Kazakhstan and Russia have signed the bilateral agreement "About the Order of contents and use of the Knot Balkhash missile warning systems located in the territory of the Republic of Kazakhstan"; according to what, the Republic of Kazakhstan transferred real and personal estate of Knot Balkhash of the Russian Federation to free use, and the Russian side undertook to provide on points of the public and military administration of Kazakhstan information from means of missile warning system and the space control system [23]. This document had important historical and political value for both states as has allowed to define the future of elements of strategic arms of the former Soviet state, having in many respects formed a basis of the RussianKazakhstan arrangements in this sector of interstate relationship.

In development of the agreements reached earlier, on December 2, 2014 in Moscow signing between the Governments of the Republic of Kazakhstan and the Russian Federation of the Agreement on conditions of transfer and on an order of further use of the Kazakhstan Knot Balkhash in the Russian missile warning system has taken place; and on October 12, 2015 this document has been ratified; among an other obliging [24]:

Russian side:

- to carry out preparation of the Kazakhstan command and engineering shots for joint operation of Knot Balkhash and executions of alert;

- until the end of 2016 to realize actions and further to carry out delivery on points of the public and military administration of the Republic of Kazakhstan of information about:

rocket situation in the automated warning system about missile attack;

development and use of space by the foreign states and international organizations in the form of monthly transfer of newsletters;

the predicted dangerous rapprochements of space objects with the operating spacecrafts of the Republic of Kazakhstan;

the predicted areas of falling of the burning-down space objects posing a threat of day of the Republic of Kazakhstan;

parameters of orbits of foreign prospecting spacecrafts for calculations in the automated warning system about flights of foreign prospecting spacecrafts over the territory of the Republic of Kazakhstan; 
Kazakhstan side:

- to provide activity of the Kazakhstan military personnel and the persons of civil personnel designated for joint operation and execution of alert on Knot Balkhash;

- to carry out antiaircraft cover of Knot Balkhash in the Uniform regional air defense system of the Republic of Kazakhstan and the Russian Federation;

- to provide exchange of information about a land, air, radio-electronic, chemical, biological, meteorological situation and threat of emergence of emergency situations around dislocation of Knot Balkhash.

\section{Summary, discussion, conclusions}

Thus, on the basis of the considered historical experience of formation and development in the territory of Kazakhstan of one of the most important components of military space activity which development and operation of missile warning systems and control of space is - it is noted that presence at Kazakhstan in the field of the state activity of the richest past, along with the tendentious growth of use in the military purposes of opportunities of near-earth space and the technical means placed in him in modern conditions staticize necessity of development of domestic initiatives in this sphere.

Modern technologies promptly get practically into all aspects of human activity, and therefore theoretically and practically reasonable vision of the perspective directions of development of military space activity of the country have to be taken out in vanguard of a complex of actions for construction of the military organization of the state; which key condition has to be a principle of implementation of preliminary preparation.

\section{REFERENCES}

[1] Tarih taғylymdary zhəne қаzirgi zaman. - Uroki istorii i sovremennost': Қазақstan Respublikasy təuelsizdiginiң bes zhyldyғуna arnalғan saltanatty zhinalysta zhasalғan bajandama. - Almaty.: Қазақstan, 1997. 128 s. (s. 70).

[2] Korporacija «Vympel». Sistemy raketno-kosmicheskoj oborony / pod red. V.V. Litvinova. - M.: Oruzhie i tehnologii, 2005. - $240 \mathrm{~s}$.

[3] Kisun'ko G.V. Sekretnaja zona: Ispoved' general'nogo konstruktora. - M.: Sovremennik, 1996. $510 \mathrm{~s}$.

[4] Raketa «Topol'» porazila cel' na poligone v Kazahstane // http://www.utro.ru/news/2010/12/05/941867.shtml 20.06.2018.

[5] Dogovor o zaprete na ispytanija jadernogo oruzhija v treh sredah: utv. 5 avgusta 1963 goda // http://ria.ru/spravka/20130805/953857752.html 20.06.2018.

[6] Drogovoz I.G. Raketnye vojska SSSR. - Minsk: Harvest, 2007. - 336 s.

[7] Severnyj V. GRANIT na grani novyh otkrytij // https://topwar.ru/44116-granit-na-grani-novyh-otkrytiy.html 20.06.2018.

[8] Gorbachev M.S. Perestrojka i novoe myshlenie dlja nashej strany i dlja vsego mira. - M.: Politizdat, 1988. - $271 \mathrm{~s}$.

[9] Parad suverenitetov. Slovar' russkogo publichnogo jazyka konca XX veka. «Kommersant\#» // https://www.kommersant.ru/doc/390624 20.06.2018.

[10] Novaja Rossijskaja jenciklopedija / pod red. A.D. Nekipelova i dr.- M.: OOO «Izdatel'stvo «Jenciklopedija»: ID «InfraM», 2007. - T. 3 (1). $-480 \mathrm{~s}$.

[11] Deklaracija o gosudarstvennom suverenitete Kazahskoj Sovetskoj Socialisticheskoj Respubliki: utv. 25 oktjabrja 1990 goda // http://online.zakon.kz/Document/?doc id=1000230 20.06.2018.

[12] Konstitucionnyj zakon Respubliki Kazahstan. O gosudarstvennoj nezavisimosti Respubliki Kazahstan: prinjat 16 dekabrja 1991 goda, №1007-XII // http://adilet.zan.kz/rus/docs/Z910004400_20.06.2018.

[13] Alma-Atinskaja Deklaracija. Edinyj reestr pravovyh aktov i drugih dokumentov Sodruzhestva Nezavisimyh Gosudarstv: utv. 21 dekabrja 1991 goda // http://cis.minsk.by/reestr/ru/index.html\#reestr/view/text?doc=4 20.06.2018.

[14] Filippov A.V. Novejshaja istorija Rossii, 1945-2006 gg.: kn. dlja uchitelja. - M.: Prosveshhenie, 2007. - 494 s.

[15] Zen'kovich N.A. Gorbachev Mihail Sergeevich. Samye zakrytye ljudi. Ot Lenina do Gorbacheva: jenciklopedija biografij. - M.: Olma-press, 2004. - 688 s.

[16] Ukaz Prezidenta Respubliki Kazahstan. O perehode gosudarstvennyh predprijatij i organizacij sojuznogo podchinenija v vedenie Pravitel'stva Kazahskoj SSR: utv. 31 avgusta 1991 goda, № 410 // http://online.zakon.kz/Document/?doc_id=1000668 20.06.2018.

[17] Ukaz Prezidenta Respubliki Kazahstan. O sozdanii Vooruzhennyh Sil Respubliki Kazahstan: utv. 7 maja 1992 goda, №745 // http://online.zakon.kz/Document/?doc_id=1001125 20.06.2018. 
[18] [Pis'mo v Kabinet ministrov Respubliki Kazahstan tov. Ezhikovu-Babahanovu E.G. ot VrIO Ministra oborony RK general-majora S. Altynbekova] // AP RK F. 5.N. Op.1. D. 382. L.83.

[19] Soglashenie o sredstvah sistem preduprezhdenija o raketnom napadenii i kontrolja kosmicheskogo prostranstva: utv. 6 ijulja 1992 goda // AP RK F. 5.N. Op. 1 D. 383. L. 102-105.

[20] Rasporjazhenie Prem'er-ministra Respubliki Kazahstan. Ob obrazovanii komissii po inventarizacii i prinjatii imushhestva voinskih chastej, prompredprijatij i organizacij kosmodroma Bajkonur, poligonov Sary-Shagan, Semipalatinsk, Jemba: utv. 19 ijulja 1993 goda, № 293-r// AP RK F. 5.N. Op. 1. D. 1673. L. 73-74.

[21] Tasbulatov A.B. Dogovor o voennom sotrudnichestve - prakticheskaja realizacija druzhby i dobrososedstva dvuh bratskih narodov // Dogovor o voennom sotrudnichestve - shag k druzhbe i kollektivnoj bezopasnosti narodov: mater. pervoj kaz.-ros. nauch.-prakt. konf. / Ұlttyқ қоrғanys universiteti. - Shhuchinsk: TOO «RISK-Biznes», 2004. - S. 10-11.

[22] Skvorcov A.S. Dogovor o voennom sotrudnichestve - prakticheskaja realizacija druzhby i dobrososedstva dvuh bratskih narodov // Dogovor o voennom sotrudnichestve - shag k druzhbe i kollektivnoj bezopasnosti narodov»: mater. 1-j kaz.ros. nauch.-prakt. konf. / Ұlttyқ қоrғanys universiteti. - Shhuchinsk: TOO «RISK-Biznes», 2004. - S. 21.

[23] Soglashenie mezhdu pravitel'stvom Rossijskoj Federacii i pravitel'stvom Respubliki Kazahstan. O porjadke soderzhanija i ispol'zovanija Uzla Balhash sistemy preduprezhdenija o raketnom napadenii, raspolozhennogo na territorii Respubliki Kazahstan: utv. 14 dekabrja 1994 goda // http://www.conventions.ru/view_base.php?id=16574 20.06.2018.

[24] Zakon Respubliki Kazahstan. O ratifikacii Soglashenija mezhdu Pravitel'stvom Respubliki Kazahstan i Pravitel'stvom Rossijskoj Federacii ob uslovijah peredachi i o porjadke dal'nejshego ispol'zovanija kazahstanskogo Uzla Balhash v rossijskoj sisteme preduprezhdenija o raketnom napadenii: prinjat 12 oktjabrja 2015 goda, № 354-V ZRK // http://adilet.zan.kz/rus/docs/Z1500000354 20.06.2018.

ӘОЖ 929, MFTAP 03.20

\author{
Д.А.Кенжебаев ${ }^{1}$ \\ ${ }^{1}$ Радиоэлектроника және байланыс әскери-инженерлік институты, Алматы, Қазақстан
}

\title{
ПОЛИГОН САРЫШАГАН - ҚЫСКАША ТАРИХИ ТАЛДАУ
}

Аннотация. Қазақстанның ғасырлық тарихы тарихи оқиғалардың ең бай көзі көбінесе салдарларды анықтаудың жаһандық ауқымымен сипатталады. Географиялық жағынан Еуропа мемлекеттері мен азиялық елдерді байланыстырып, Қазақстан өзінің тарихи дамуына әлемдік мемлекеттердің карым-катынасына тікелей ықпал етті. Осындай карым-катынас әскери қауіпсіздікті қамтамасыз ету және әскери өнердің саласын, ғылым, техника мен технологияларды дамуы келісілген геосаясат тайталастары тарихи зерттеулер контекстінде анықталады. Осыған байланысты қазіргі заман шартына жалпы әскери-ғарыш бағыты ғылыми ізденіспен нақты тарихи зерттеулердің өзекті сипатын береді. Қазақстан Республикасының аумағы тарихи негізде зымырандық-ғарыштық технологияларды дамыту саласындағы практикалық салтанатты ғылыми ойлар отаны және жинағы болды, бұл өз кезегінде қосымша зерттеулер жүргізу қажетті болды олардың мақсаты тарихи фактілерді және маңызды оқиғалар өзінің кешенінде көріну бар заттардың тәртібі және мемлекетаралық қарым-қатынастың мән-жайларын анықтау керек. Айтылған контексте Қазақстан аумағында әскери-ғарыштық қызметін құрайтын, атап айтқанда зымыранға қарсы құрамдас бөлігін дамыту, оны жүзеге асыру, тарихи тәжірибесі қарастырылған. Келтірілген талдау шеңберінде тарихи алғышарттары мен шарттары осы бағыт қалыптастыру мемлекеттік қызметтегі оның тарихнама бөлінісінде қазіргі жағдайда одан әрі дамыту ашылады. Кеңес мемлекетінің ыдырауы және тәуелсіз Қазақстанның қалыптасуы тарихи сәтінде мемлекеттік органдарының іс-әрекеттері көрсетілген, мемлекетаралық келісімдерді нәтижелері айқындалған, оларды әрі қарай орындау перспективалары анықталған. Тұтастай алғанда, бірқатар жаңа көздеріне сүйене отырып зымыранға қарсы қорғаныс жүйесін дамыту тарихи процестің тарихнамасы Қазақстан аумағында контексінде мазмұнын ашудың тиісті қызметті жүзеге асырылған.

Түйін сөздер: Сарышаган, Балқаш торабы, зымыран шабуыл туралы ескертудің жүйесі. 
УДК 929, МРНТИ 03.20

\author{
Д.А.Кенжебаев ${ }^{1}$ \\ ${ }^{1}$ Военно-инженерный институт радиоэлектроники и связи, Алматы, Казахстан
}

\title{
ПОЛИГОН САРЫШАГАН - КРАТКИЙ ИСТОРИЧЕСКИЙ АНАЛИЗ
}

Аннотация. Многовековая история Казахстана являет собой богатейший кладезь исторических событий зачастую характеризуемых глобальными масштабами определяющих последствий. Географически связуя европейские государства с азиатскими странами, Казахстан в своем историческом развитии подчас имел самое непосредственное влияние на взаимоотношение мировых государств. Подобные взаимосвязи выявляются в контексте исторических исследований геополитических конфронтаций обусловленных развитием науки, техники и технологий в сфере обеспечения военной безопасности и развития военного искусства. В этой связи в условиях современности актуализируется военно-космическое направление научного поиска вообще и исторических исследований в частности. Территория Республики Казахстан исторически обоснованно стала родиной и средоточием воплощения практического торжества научной мысли в сфере развития ракетно-космических технологий, что в свою очередь актуализирует проведение дополнительных исследований целью которых должно стать определение исторических фактов и определяющих событий в комплексе своего проявления обусловивших существующий порядок вещей и коньюктуру межгосударственных взаимоотношений. В контексте сказанного в данной статье рассматривается исторический опыт осуществления на территории Казахстана одной из составляющих военно-космической деятельности, а именно развитие ее противоракетной составляющей. В рамках приведенного анализа раскрываются исторические предпосылки и условия формирования данного направления государственной деятельности в разрезе историографии ее зарождения и дальнейшего развития в современных условиях. Показаны действия государственных органов в исторический момент развала советского государства и становления независимого Казахстана, выявлены результаты межгосударственных договоренностей; определены перспективы их дальнейшего исполнения. В целом, опираясь на ряд новых источников, представлен непредвзятый взгляд на историографию исторического процесса развития системы противоракетной обороны в контексте раскрытия содержания соответствующей деятельности осуществленной на территории Казахстана.

Ключевые слова: Сарышаган, Узел Балхаш, система предупреждения о ракетном нападении.

Information about author:

Kenzhebayev Daulet Anuarbekuly - Military and engineering institute of radio electronics and communication, Almaty, Kazakhstan, chief of department of Bases of military radio technique and electronics, doctor of philosophy (PhD), daulet.0117@,rambler.ru, https://orcid.org/0000-0003-3299-5930 


\section{МАЗМҰНЫ}

Алтыбаева С.М., Савындыков Е.С. Көркем мәтін құрылымындағы мифопоэтикалық модельдеу және мәдени код...... 5 Сембиева Л.М., Мажитов Д.М., Карпиикая М.Е., Хамитова Д.М. Экономиканы жаңғырту жағдайындағы ЕАЭО елдерінің монетарлық жүесінін өзгеруі .....

Құлсариева А.Т., Султанова М.Э., Шайгозова Ж.Н. Фольклор және сәйкестілік: Қазақстанның қазіргі заманғы

мәдениетіндегі тарих, жады және аңыз шығармашылығы ........................................................................................... 19

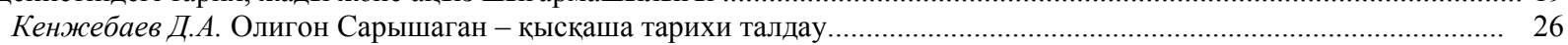

АбдулинаГ.А., БазарбаевА.Г. Ұйымдардағы адам ресурстарын басқарудың заманауи тұжырымдамалары................ 33

Авыбаев А.Н., Адибаева А.К. Геноцид туралы БҰҰ Конвенциясының қатысушы мемлекеттердің қылмыстық

заңнамаларындағы имплементациялық тетіктері: жалпы салыстырмалы талдау............................................................ 39

Ахметжанов Б., Тәжібекова К.Б., Шаметова А.А. Қазақстан көлік өнеркәсіптің дамуын талдау............................. 44

Аюпова 3.К., Құсайынов Д.Ө. Тәуелсіздік жағдайындағы қазақстан республикасының конституциялық-құқықтық

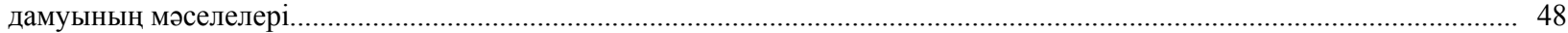

Нурпеисова А.А., Рей И.Ю., Бижанов Д.Т., Тлеужанова Д.А. Инновациялық өндірісді жасаудың процесін

бақылауының негізгі элементтері

Гиздатов Г.Г. Қазақстандық дискурсының құрылымы психолингвистиякалық зерттеу .

Ищанова Р.К. Мемлекеттік шығындарды басқару - мемлекеттің қаржылық тұрақтылығын қамтамасыз ету.............. 64

Мадышева А.М. Бикенова А.С., Елеусиз Л.Т. Білім саласындағы туристік қызметтер............................................. 68

Ескалиева А. Ж., Баймуханова М.Т., Ахмурзина Д.О. Әлеуметтік сала адам капиталының сапасын қолдаудың

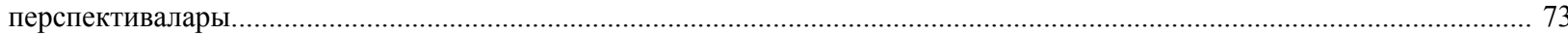

Мархаева Б.А., Козбахова Д.Л. Жауапкершілік орталық және трансферттік баға белгілеу............................................ 79

Сабирова Р.К., Утепкалиева К.М., Кабаков С.Б. Қазақстандағы ауыл шаруашылығы экономикасының

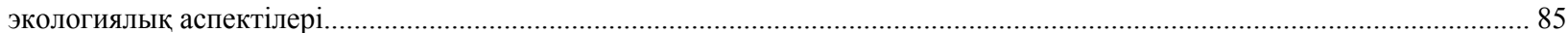

Тлесова Э., Хойч А., Кураш Н. Қазақстан республикасының ғылыми инновациялық потенциясы және оның

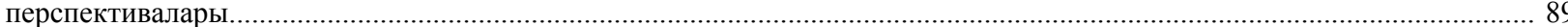

Хамитхан Н. Қазақстандағы банктік қызметтердің сапасын жақсарту жағдайында банкаралык басекелестік............ 95

Шалдарбеков Қ.Б., Муханова Г.С., Нурмухамбетова 3.С. Аймақтарды дамыту бағдарламаларын жүзеге асырудағы жобалық басқаруды қолданудың шетелдік тәжірибесі

КаратаеваА.М., Бердиярова Ж.С. Мемлекеттік қызметшінің әдептік мәдениеті және құқықтық мәдениеті

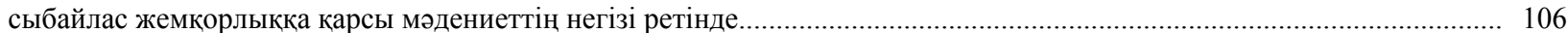

Алдабергенова А.А. Абсурд әдебиетін аударудың лингвомәдени аспектілері ................................................... 113

Стукач В. Ф., Байдалинова А. С., Сандыбаева Б. А. Қазақстанның қаржылық қауіпсіздігі......................................... 119

Баймаханова Д.М., Оспанова Д.А. Конституциялық-құқықтық сана - конституционализмнің маңызды

компоненті ретінде және оның адам құқықтары мәселелерін шешудегі рөлі................................................................. 126

Имангожина 3.А. Сланцевая революция: глобальный тренд на мировом энергетическом рынке............................. 137

Ракаева А.Н., Жуматаева Б.А., Успамбаева М.К., Доскалиева Б.Б. Экологиялық есеп қазақстандағы кәсіпорын экономикасының даму кезеңі ретінде

Нуржанова Г.И. Экономиканың аграрлық секторындағы еңбек әлеуетіне демографиялық фактордың әсері............ 147

Оспанова Д.А., Баймаханова Д.М. Қазақстан Республикасының кибер кеңістігін дамыту жағдайында мемлекеттік қызметтерді цифрландыруда әкімшілік-құқықтық қамтамасыз ету ................................................................................... 152

Pblсnекова М.О., Тлесова Э.Б., Хаитбаева Ф.К. Қазақстандағы тұрғын үй-коммуналдық шаруашылық қызметін

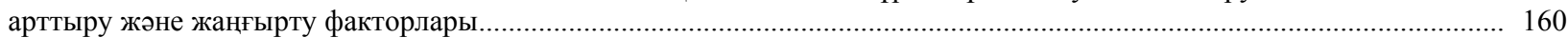

Султанова Г. Т. Аграрлық сектордың экспорттық әлеуетін дамытуға бағытталған үрдістер мен басымдықтар........ 166 


\section{СОДЕРЖАНИЕ}

Алтыбаева С.М., Сагындыков Е.С. Культурный код и мифопоэтическое моделирование в структуре художественного текста

Сембиева Л.М., Мажитов Д.М., Карпиикая М.Е., Хамитова Д.М. Трансформация монетарной системы стран

ЕАЭС в условиях модернизации экономики

Кулсариева А.Т., Султанова М.Э., Шайгозова Ж.Н. Фольклор и идентичность: история, память и мифотворчество

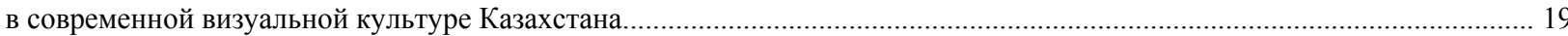

Кенжебаев Д.А. Полигон Сарышаган - краткий исторический анализ................................................................ 26

Абдулина Г.А., БазарбаевА.Г. Современные концепции управления человеческми ресурсами в организациях............ 33

Агыбаев А.Н., Адибаева А.К. Имплементационные механизмы Конвенции ООН о геноциде в уголовных

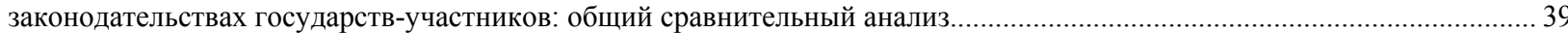

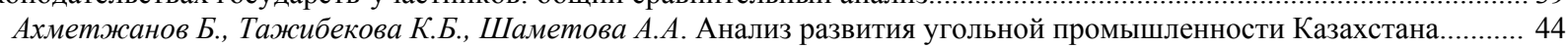

Аюпова 3.К., Кусаинов Д.У.Проблемы конституционно-правового развития республики Казахстан в условиях суверенитета ......

Нурпеисова А.А., Рей И.Ю., Бижанов Д.Т., Тлеужанова Д.А. Основные элементы управления процессом создания инновационной продукции ....

Гиздатов Г.Г. Психолингвистическое исследование концептов казахстанского дискурса......

Ищанова Р.К. Управление государственными расходами - как обеспечение финансовой устойчивости государства. 64

Мадышева А.М. Бикенова А.С., Елеусиз Л.Т. Туристские услуги в сфере образования................................................. 68

Ескалиева А. Ж., Баймуханова М.Т., Ахмурзина Д.О. Перспективы усиления качества человеческого капитала

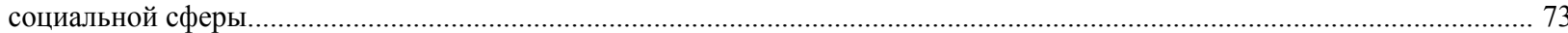

Мархаева Б.А., Козбахова Д.Л. Центр ответственности и трансфертное ценообразование....................................... 79

Сабирова Р.К., Утепкалиева К.М., Кабаков С.Б. Экологические аспекты экономики сельского хозяйства

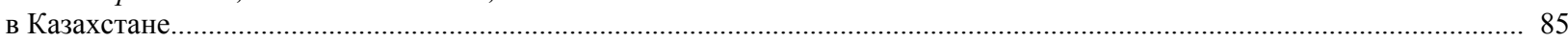

Тлесова Э., Хойч А., Кураш Н. Научно-инновационный потенциал республики Казкастан и его перспективы............ 89

Хамитхан Н. Межбанковская конкуренция в условиях повышения качества банковских услуг в Казахстане..............95

Шалдарбеков К.Б., Муханова Г.С., Нурмухамбетова З.С. Зарубежный опыт применения проектного управления

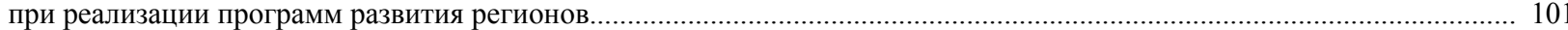

Каратаева А.М., Бердиярова Ж.С. Этическая культура и правовая культура государственных служащих

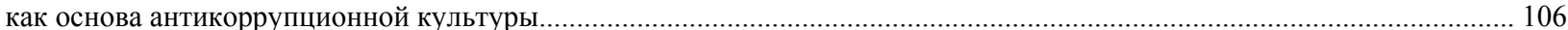

Алдабергенова А.А. Лингвокультурологические аспекты перевода литературы абсурда........................................... 113

Стукач В. Ф., Байдалинова А. С., Сандыбаева Б. А. Казахстанская финансовая безопасность................................... 119

Баймаханова Д.М., Оспанова Д.А. Конституционно-правовое сознание как важный компонент конституционализма

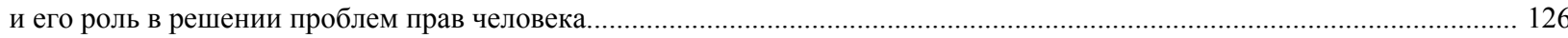

Имангожина 3.А. Сланцевая революция: глобальный тренд на мировом энергетическом рынке............................ 137

Ракаева А.Н., Жуматаева Б.А., Успамбаева М.К., Доскалиева Б.Б. Экологический учет как ступень развития

экономики предприятия в Казахстане............................................................................................

Нуржанова Г.И. Влияние демографического фактора на трудовой потенциал аграрного сектора экономики............ 147

Оспанова Д.А., Баймаханова Д.М. Административно-правовое обеспечение цифровизации государственных услуг в условиях развития кибер пронстранства республики Казахстан......

Рыспекова М.О., Тлесова Э.Б., Хаитбаева Ф.К. Факторы инновационной модернизации и совершенствования деятельности жилищно-коммунального хозяйства в Казахстане

Султанова Г. Т. Тенденции и приоритеты развития экспортного потенциала аграрного сектора... 


\section{CONTENTS}

Altybayeva S.M., Sagyndykov E.S. Cultural code and myth poetic modeling in the structure of the artistic text..................... 5 Sembiyeva L.M., Mazhitov D.M., Karpitskaya M.E., Khamitova D.M. Transformation of the monetary system of the eurasian economic UNION countries in the conditions of modernization of the economy......

Kulsarieva A.T., Sultanova M.E., Shaigozova Zh.N. Folklore and identity: history, memory and myth-making in the modern

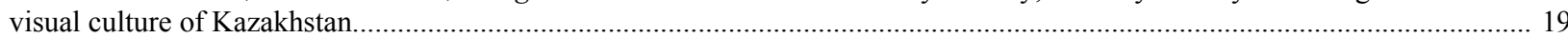

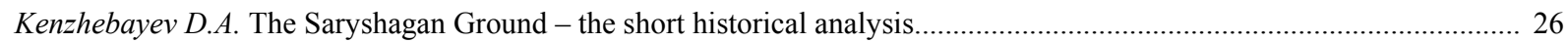

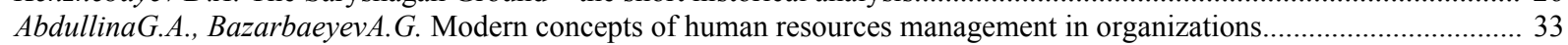

Agybayev A.N., Adibayeva A.K. Implementing mechanisms of the UN Convention on genocide in the criminal legislation

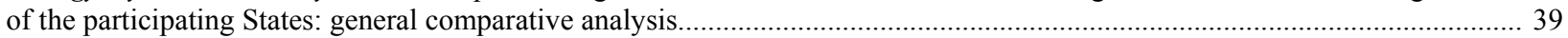

Akhmetzhanov B., Tazhibekova K.B, Shametova A.A. Analysis of development of the coal industry of Kazakhstan.............. 44 Ayupova Z.K., Kussainov D.U. Problems of constitutional and legal development of the republic of kazakhstan in the conditions of sovereignty......

Nurpeisova A.A., Rey I.Yu., Bizhanov D.T., Tleuzhanova D.A. Main elements of managing the process of creating innovation production.

Gizdatov G.G. Psycholinguistic study of the concepts of Kazakhstar

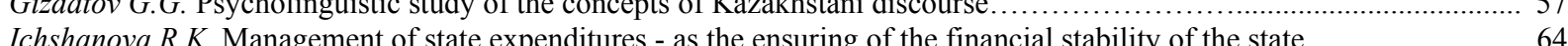

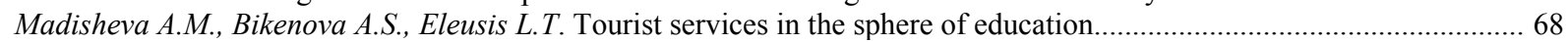

Eskalieva A. Zh., Baymukhanova M.T., Ahmurzina D.O. Perspectives of strengthening the quality of the human capital

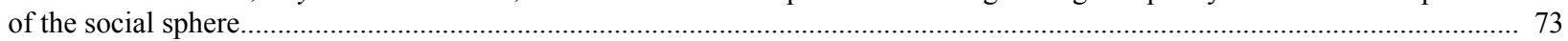

Markhayeva B.A., Kozbakhova D.L. A responsibility center and transfer pricing ................................................. 79

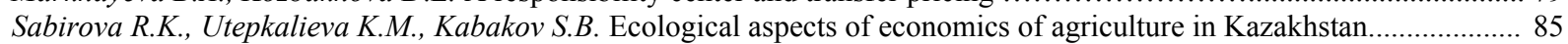

Tlessova E., Khoich A., Kurash N. Scientific innovation potential of the republic of Kazkahstan and its perspectives........ 89

Hamitkhan $N$. Interbank competition in conditions of improving the quality of banking services in Kazakhstan.................. 95

Shaldarbekov K., Mukhanova G., Nurmukhambetova Z. International practices in project management in implementing

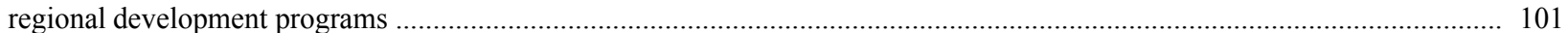

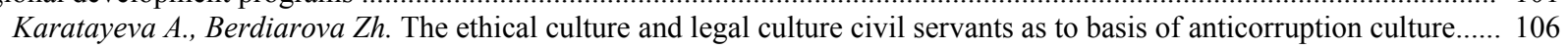

Aldabergenova A.A. Linguocultural aspects of translation of absurd literature.............................................................. 113

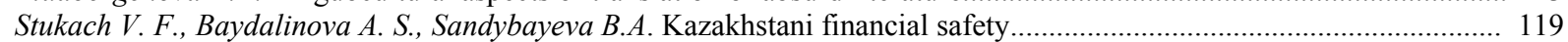

Baimakhanova D.M., Ospanova D.A. Constitutional and legal consciousness as an important component of constitutionalism

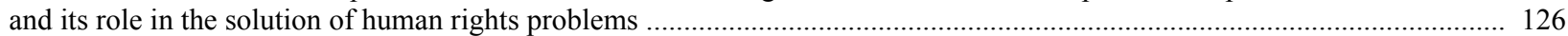

Imangozhina Z.A. Shale gas revolution: global trend in the world energy market..................................................... 137

Rakaeva A.N., Zhumataeva B.A., Uspanbayeva M.K., B.B.Doskalieva. Level of ecological report development in the economic of Kazakhstan's companies.

Nurzhanova G.I. Impact of demographic factors on labor potential of economy's agricultural sector

Ospanova D.A., Baimakhanova D.M. Administrative and legal support of digitalization of public services in the context of the development of cyber space in the republic of Kazakhstan....

Ryspekova M.O., Tlessova E.B., Khaitbayeva F. Factors of innovative modernization and improvement of activity

of housing and communal services in Kazakhstan.

Sultanova G. T. Trends and priorities for the development of export potential of the agrarian sector. 


\title{
PUBLICATION ETHICS AND PUBLICATION MALPRACTICE IN THE JOURNALS OF THE NATIONAL ACADEMY OF SCIENCES OF THE REPUBLIC OF KAZAKHSTAN
}

For information on Ethics in publishing and Ethical guidelines for journal publication see http://www.elsevier.com/publishingethics and http://www.elsevier.com/journal-authors/ethics.

Submission of an article to the National Academy of Sciences of the Republic of Kazakhstan implies that the work described has not been published previously (except in the form of an abstract or as part of a published lecture or academic thesis or as an electronic preprint, see http://www.elsevier.com/postingpolicy), that it is not under consideration for publication elsewhere, that its publication is approved by all authors and tacitly or explicitly by the responsible authorities where the work was carried out, and that, if accepted, it will not be published elsewhere in the same form, in English or in any other language, including electronically without the written consent of the copyrightholder. In particular, translations into English of papers already published in another language are not accepted.

No other forms of scientific misconduct are allowed, such as plagiarism, falsification, fraudulent data, incorrect interpretation of other works, incorrect citations, etc. The National Academy of Sciences of the Republic of Kazakhstan follows the Code of Conduct of the Committee on Publication Ethics (COPE), and follows the COPE Flowcharts for Resolving Cases of Suspected Misconduct (http://publicationethics.org/files/u2/New Code.pdf). To verify originality, your article may be checked by the originality detection service Cross Check http://www.elsevier.com/editors/plagdetect.

The authors are obliged to participate in peer review process and be ready to provide corrections, clarifications, retractions and apologies when needed. All authors of a paper should have significantly contributed to the research.

The reviewers should provide objective judgments and should point out relevant published works which are not yet cited. Reviewed articles should be treated confidentially. The reviewers will be chosen in such a way that there is no conflict of interests with respect to the research, the authors and/or the research funders.

The editors have complete responsibility and authority to reject or accept a paper, and they will only accept a paper when reasonably certain. They will preserve anonymity of reviewers and promote publication of corrections, clarifications, retractions and apologies when needed. The acceptance of a paper automatically implies the copyright transfer to the National Academy of sciences of the Republic of Kazakhstan.

The Editorial Board of the National Academy of sciences of the Republic of Kazakhstan will monitor and safeguard publishing ethics.

Правила оформления статьи для публикации в журнале смотреть на сайте:

$$
\begin{gathered}
\text { www:nauka-nanrk.kz } \\
\text { social-human.kz }
\end{gathered}
$$

\author{
Редакторы М.С. Ахметова, Т.А. Апендиев, Д.С. Аленов \\ Верстка на компьютере А.М. Кульгинбаевой \\ Подписано в печать 10.10.2018 \\ Формат 60x881/8. Бумага офсетная. Печать - ризограф. \\ 11,6 п.л. Тираж 500. Заказ 5.
}

